\title{
Correlation between trough levels of infliximab and postoperative endoscopic recurrence in Crohn's disease patients submitted to ileocolonic resections: a systematic review
}

\author{
Fernanda da Silva Barbosa BARAÚNA and Paulo Gustavo KOTZE
}

Received: 29 April 2020

Accepted: 17 September 2020

\begin{abstract}
Background - The rates of postoperative endoscopic recurrence (PER) in patients with Crohn's disease (CD) are consistent. Anti-TNF therapy has been increasingly used in the postoperative setting, despite the lack of robust data in the literature on the measurement of trough levels and consequences of their use. Objective - The aim of this review was to assess trough levels of infliximab (IFX) in CD patients after ileocolonic resections in correlation with the presence of PER. Methods - We searched for studies that evaluated trough levels of IFX in patients with CD, who underwent ileocaecal resections, and correlated them with the presence of PER. We used MEDLINE through PubMed and CENTRAL Cochrane library databases, and after matching the inclusion criteria, the studies were methodologically evaluated with qualitative analysis of the data. Results - A total of 155 studies were initially identified in the databases search and only four matched the inclusion criteria. They comprised one prospective cohort study, one randomized controlled trial and two retrospective cohort studies, the last one performed in pediatric patients. This evidence suggested the correlation of PER with low trough levels of IFX and the presence of antibodies to the drug. The quality of the evidence generated varied from very low to high, due to the heterogeneity found between the studies and the risks of bias that were identified. Conclusion - Low levels of IFX and the presence of antibodies to the drug were directly associated with increased PER rates in patients with CD, who underwent ileocolonic resections. Controlled and randomized clinical trials with adequate methodological quality are warranted to confirm the conclusions from this systematic review.
\end{abstract} HEADINGS - Crohn disease. Recurrence. Infliximab. Drug monitoring.

\section{INTRODUCTION}

Crohn's disease $(\mathrm{CD})$ is a chronic autoimmune inflammatory disorder, of unknown etiology, which can affect any segment of the digestive tract, with variable intensity and unpredictable clinical course. It is estimated that up to $80 \%$ of patients with CD will need surgery at some point in their disease course, with $40 \%$ going through more than one surgical intervention. Refractory symptoms to medical therapy (corticosteroids, immunomodulators and biological therapy), bowel obstruction due to strictures and formation of fistulas or abscesses are the main indications for surgery. The most common abdominal surgical procedure in $\mathrm{CD}$ is ileocolonic resection ${ }^{(1-3)}$.

Despite providing a prolonged period of disease control, surgery is not curative, and recurrence rates are high. Recurrence can be histological, endoscopic, clinical or combined, and histological and endoscopic lesions usually precede and predict clinical symptoms ${ }^{(2)}$. The severity of endoscopic lesions after ileocolonic resections has been traditionally assessed using the Rutgeerts' score $^{(4)}$. In the original study, ileocolonoscopy was performed 1 year after surgery and lesions in the neo-terminal ileum were scored as follows: i0 (without lesions), i1 ( $<5$ erosions/aphthoid ulcers), i2 ( $>5$ erosions/ aphthoid ulcers with normal mucosa between lesions or large lesions confined to anastomosis), i3 (diffuse ileitis with erosions/ aphthoid ulcers) and i4 (diffuse inflammation with ulcers, nodules and/ or luminal narrowing). Postoperative endoscopic recurrence (PER) is defined as a Rutgeerts score $\geq 2$.

Studies demonstrated that in patients undergoing ileocolonic resections, endoscopic recurrence rates can be as high as $73 \%$ in 1 year and $85 \%$ in 3 years after surgery ${ }^{(3)}$. Some factors were associated with an increased risk of PER: male gender, active smoking, penetrating phenotype, extensive small bowel resection $(>50 \mathrm{~cm})$ and previous use of corticosteroids ${ }^{(1)}$.

The efficacy of tumor necrosis factor (TNF) alpha inhibitors in preventing endoscopic recurrence after ileocolonic resections has been established and demonstrated by several studies ${ }^{(2,5,6)}$. A recent systematic review demonstrated that anti-TNF therapies, both in mono or in combination with immunomodulators, appear to be the most effective agents to prevent PERin $\mathrm{CD}^{(3)}$. However, such agents are not used for all patients, in order to avoid overtreatment in cases of slower disease progression and for cost reasons. Thus, the indication for anti-TNFs after surgery is indeed reserved for cases of patients with risk factors for recurrence.

Serum infliximab (IFX) levels are associated with clinical

Declared conflict of interest of all authors: Kotze PG has received consultancy and speaking honorarium from Abbvie, Janssen, Pfizer and Takeda.

Disclosure of funding: no funding received

Pontíficia Universidade Católica do Paraná (PUCPR), Hospital Universitário Cajuru, Ambulatório de Doenças Inflamatórias Intestinais, Curitiba, PR, Brasil.

Corresponding author: Fernanda da Silva Barbosa Baraúna. E-mail: drafernanda.proctologia@gmail.com 
response, disease remission and mucosal healing. In a systematic review, Moore et al. ${ }^{(7)}$ demonstrated that during maintenance therapy, patients in clinical remission had significantly higher serum levels immediately before the next dose (trough levels) of IFX than individuals who were not in remission. Patients with an IFX level $>2 \mu \mathrm{g} / \mathrm{mL}$ were more likely to be in clinical remission or achieve endoscopic remission than patients with levels $<2 \mu \mathrm{g} /$ $\mathrm{mL}$. In a randomized study, Van de Casteele et al. ${ }^{(8)}$ observed that trough levels of IFX were higher in patients with mucosal healing at endoscopic examination than in patients with active disease at endoscopy. In the study by Maser et al..$^{(9)}$ the rates of clinical remission were higher in patients with a detectable serum level of IFX as compared to patients in whom serum IFX was undetectable, including those without antibodies $(82 \%$ versus $6 \%$ ). In a similar scenario, Imaeda et al. ${ }^{(10)}$ demonstrated that there was endoscopic improvement in patients with mean IFX levels $>1.4 \mu \mathrm{g} / \mathrm{mL}$ as compared to patients in whom serum IFX was undetectable.

Although there is adequate evidence of the efficacy of antiTNFs in preventing endoscopic recurrence after ileocolonic resections, the impact of serum drug levels on PER has been poorly explored. Due to the scarce evidence related to the topic in the literature and the potential for a therapeutic strategy to be studied, we conducted a systematic review in order to assess studies which correlated trough levels of IFX in CD patients that underwent ileocolonic resections with the presence or not of postoperative endoscopic recurrence.

\section{METHODS}

\section{Search strategy}

This review was carried out in accordance with the recommendations of the Preferred Reporting Items for Systematic Reviews and Meta-Analyses (PRISMA) Guidelines ${ }^{(11,12)}$. The published studies were identified after search conducted in Medline electronic databases via PubMed https://www.ncbi.nlm. nih.gov/pubmed/ and CENTRAL Cochrane library [https://www. cochranelibrary.com/] in January 2020, using five different search instruments, with the terms: (Crohn's disease) and (recurrence) and (infliximab) and (levels); (Crohn's disease) and (recurrence) and (infliximab) and (serum); (Crohn's disease) and (recurrence) and (therapeutic drug monitoring); (Crohn's disease) and (endoscopic recurrence) and (therapeutic drug monitoring); (Crohn's disease) and (endoscopic recurrence) and (ileocolonic resection) and (infliximab).

\section{PICO model}

According to the PICO model (population; intervention; control; outcome $)^{(13)}$ we sought for studies that evaluated serum levels of IFX in patients with CD that underwent ileocolonic resection and were using this anti-TNF agent after surgery, correlating them with the presence or not of postoperative endoscopic recurrence.

\section{Eligibility and inclusion and exclusion criteria}

Studies to be considered eligible should meet the following inclusion criteria: analysis of patients with $\mathrm{CD}$, submitted to ileocolonic resections and treated with IFX in the postoperative period; evaluation of endoscopic recurrence with colonoscopy; and assessment of serum levels (trough levels) of IFX after surgery. No restrictions were applied in relation to patients' age, date of publication or language. All studies classified under at least one of the following conditions were excluded: review articles, guidelines, consensus articles, editorials or case reports; studies involving patients with other diseases than CD; studies with other drugs than IFX; studies using animal models.

\section{Study selection and data collection process}

Through electronic databases or by manual search, studies were selected, independently by two reviewers (FSBB and PGK), after removing duplicate records. Any study whose title and abstract did not indicate inclusion in the eligibility criteria was excluded from further analyses. In all other studies, the full text was assessed to determine its inclusion or exclusion.

The following data were collected from the selected studies: journal, year of publication, name of the authors, type of article, number of patients, age, sex, disease location, duration of the disease, smoking, history of medications for CD before surgery, previous surgical procedures, concomitant use of immunomodulators, duration of treatment with IFX, postoperative colonoscopy and trough levels of IFX.

\section{Evaluation of methodological quality of studies}

The methodology of the selected studies was evaluated using the Cochrane Collaboration's tool ${ }^{(14)}$ for randomized clinical trials (RCTs) and the Methodological Index for non-randomized studies (MINORS) ${ }^{(15)}$ for non-randomized clinical trials and for observational studies. The risk of bias was judged as "low", "high" and "uncertain" when the Cochrane Collaboration's tool was used. When MINORS was used, the items were scored with "0" (not reported), "1" (reported, but inappropriately) or " 2 " (reported appropriately). The ideal final score would be 16 for non-comparative studies and 24 for comparative studies.

\section{Statistical analysis}

The small number of studies and their respective methodologies allowed only a qualitative analysis of the data. In descriptive components, means, medians, standard deviations and percentages were calculated. A meta-analysis was not performed in view of the small number of patients, lack of control and heterogeneous nature of the studies.

\section{RESULTS}

\section{Bibliographic search and study selection}

FIGURE 1 summarizes the study selection process. The search in the electronic databases identified 145 studies; 10 others were added by the authors by manual search. Overall, 48 studies were immediately excluded because they were duplicated. After reviewing the title and abstract of the remaining 107 studies, 27 were considered for full text analysis. At the end of the review, four articles were included for qualitative analysis, while the other 23 were excluded for respective reasons described in the flowchart.

\section{Methodological quality of included studies}

FIGURE 2 describes the Cochrane Risk of bias tool for the randomized control study and the criteria used for its evaluation. TABLE 1 presents more information about the criteria used in MINORS, for non-randomized studies, in addition to the scores of each manuscript in this methodological quality assessment instrument. 


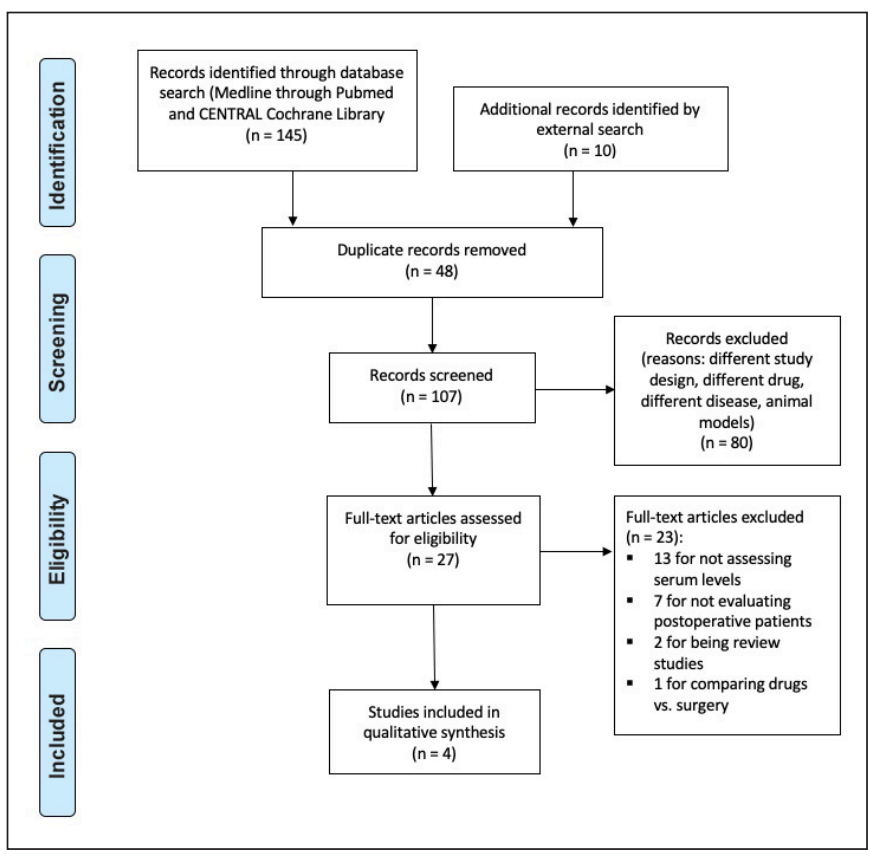

FIGURE 1. Systematic review PRISMA flow diagram.

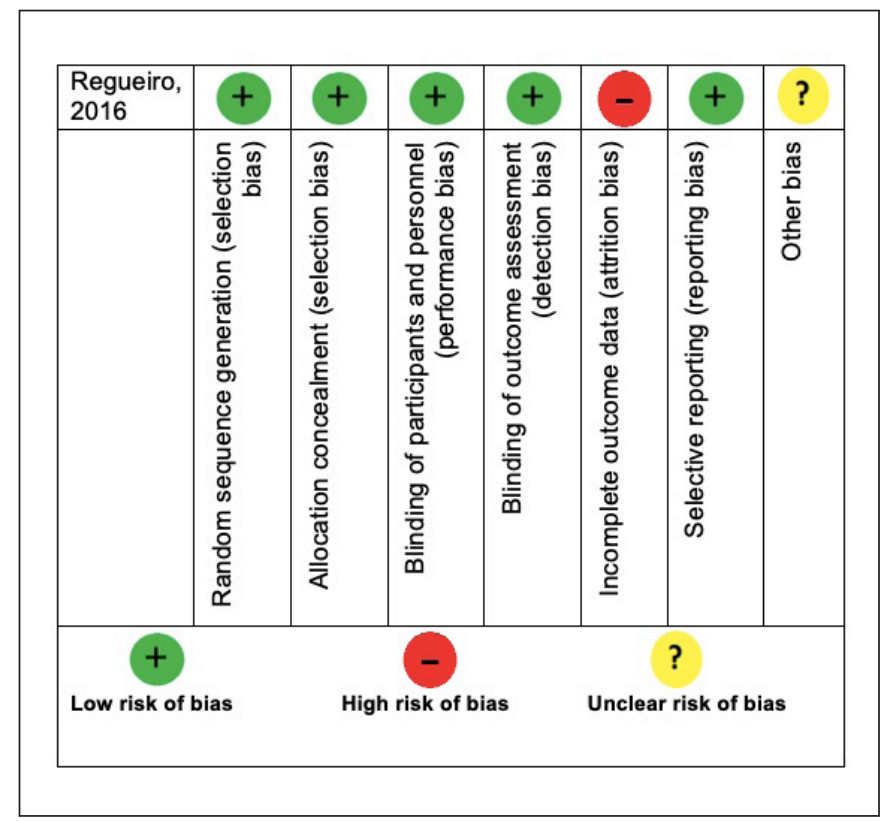

FIGURE 2. Cochrane Risk of Bias Tool for randomized trials.

\section{Characteristics of the studies}

Of the four articles included for the qualitative analysis, one was a prospective cohort study ${ }^{(16)}$, one was a randomized clinical trial $^{(17)}$ and two were retrospective cohort studies ${ }^{(18,19)}$, the last being exclusively in pediatric patients ${ }^{(19)}$. The number of patients ranged from 11 to 297, totalizing 404 patients included in the selected studies $^{(16,17)}$.

A study dosed serum levels of IFX and anti-IFX antibodies, in five consecutive patients who had clinical and endoscopic remission after one year of treatment with IFX at a dose of $3 \mathrm{mg} / \mathrm{kg}$ and
TABLE 1. Methodological Index for Non-randomized studies (MINORS) for evaluation of non-randomized clinical trials and observational studies included. Items are scored as 0 (not reported), 1 (reported, but inadequate) or 2 (reported and adequate). The global ideal score is 16 for non-comparative studies and 24 for comparative studies.

\begin{tabular}{|c|c|c|c|}
\hline & $\begin{array}{l}\text { Sorrentino, } \\
2015\end{array}$ & $\begin{array}{l}\text { Fay, } \\
2017\end{array}$ & $\begin{array}{l}\text { Van Hoeve, } \\
2018\end{array}$ \\
\hline A clearly stated aim & 2 & 2 & 2 \\
\hline $\begin{array}{l}\text { Inclusion of consecutive } \\
\text { patients }\end{array}$ & 2 & 2 & 1 \\
\hline Prospective collection of data & 2 & 1 & 1 \\
\hline $\begin{array}{l}\text { Endpoints appropriate to the } \\
\text { aim of the study }\end{array}$ & 2 & 2 & 2 \\
\hline $\begin{array}{l}\text { Unbiased assessment of the } \\
\text { study endpoint }\end{array}$ & 0 & 0 & 0 \\
\hline $\begin{array}{l}\text { Adequate follow-up period to } \\
\text { the aim of the study }\end{array}$ & 2 & 0 & 2 \\
\hline Loss to follow-up $<5 \%$ & 2 & 0 & 0 \\
\hline $\begin{array}{l}\text { Prospective calculation of the } \\
\text { study sample }\end{array}$ & 2 & 0 & 1 \\
\hline \multicolumn{4}{|c|}{ Additional criteria for comparative studies } \\
\hline Adequate control group & 2 & & \\
\hline Contemporary groups & 2 & & \\
\hline $\begin{array}{l}\text { Baseline equivalence of } \\
\text { groups }\end{array}$ & 2 & & \\
\hline Adequate statistical analyses & 2 & & \\
\hline Total & 22 & 7 & 9 \\
\hline
\end{tabular}

compared with a control group of 6 patients who did not undergo surgery and were in remission with a dose of $5 \mathrm{mg} / \mathrm{kg}$ of IFX ${ }^{(16)}$.

The clinical trial assessed the effectiveness of IFX in preventing postoperative recurrence in 297 patients who were randomized into a group that received IFX $5 \mathrm{mg} / \mathrm{kg}$ and another that received placebo every 8 weeks for 200 weeks, with the primary outcome being assessed for clinical recurrence and the secondary, endoscopic recurrence. $^{(17)}$

The retrospective cohort in adults included 73 consecutive postoperative patients treated with IFX (32 patients) or adalimumab (41 patients) $)^{(18)}$. For this qualitative analysis, only data from patients using IFX were used. Serum levels of the drug and anti-IFX antibodies were correlated to the Rutgeerts' score at colonoscopy, assessed after a period of at least 6 months after surgery, ranging from 7 to 43 months. The average time between the colonoscopy and the serum level of IFX dosage was 29 days, varying between 0 and 90 days.

The pediatric population study was a retrospective analysis of medical records, which included 52 children (33 with Crohn's disease and 19 with ulcerative colitis), with only $2(3.8 \%)$ in the postoperative period who used IFX and had serum levels of the drug correlated with clinical, biochemical and endoscopic remission ${ }^{(19)}$. The results were not separated by disease, nor patients who did not undergo surgery were differentiated from those who underwent a surgical procedure.

TABLE 2 shows in detail the characteristics of the included studies, as well as the clinical and demographic aspects of the patients. 
TABLE 2. Characteristics of selected studies and clinical and demographic profile of patients.

\begin{tabular}{|c|c|c|c|c|c|c|}
\hline \multirow[b]{2}{*}{ Journal } & \multicolumn{2}{|c|}{ Sorrentino, 2015} & \multicolumn{2}{|c|}{ Regueiro, 2016} & Fay, 2017 & Van Hoeve, 2018 \\
\hline & \multicolumn{2}{|c|}{ PLoS ONE } & \multicolumn{2}{|c|}{ Gastroenterology } & $\begin{array}{l}\text { Inflammatory } \\
\text { bowel diseases }\end{array}$ & $\begin{array}{l}\text { Journal of Crohn's } \\
\text { and colitis }\end{array}$ \\
\hline Study design & \multicolumn{2}{|c|}{ Cohort prospective } & \multicolumn{2}{|c|}{$\begin{array}{l}\text { Prospective, multicenter, } \\
\text { randomized, double-blind CT }\end{array}$} & $\begin{array}{c}\text { Cohort } \\
\text { retrospective }\end{array}$ & $\begin{array}{l}\text { Cohort, retrospective, } \\
\text { pediatric patients }\end{array}$ \\
\hline $\begin{array}{l}\text { Number of patients, } \mathrm{n} / \\
\text { intervention }\end{array}$ & $5 / \mathrm{IFX}$ & $\begin{array}{l}6 / \text { non postoperative } \\
\text { patients using IFX }\end{array}$ & 150 / Placebo & 147 / IFX & $\begin{array}{c}73 \\
32 / \text { IFX } \\
41 / \mathrm{ADA}\end{array}$ & $\begin{array}{c}52 / \text { IFX } \\
\text { 33: CD - } 2 \text { postoperative } \\
\text { 19: UC }\end{array}$ \\
\hline $\begin{array}{l}\text { Disease duration in } \\
\text { years, median }\end{array}$ & 8 & 5.5 & 3.32 & 6.49 & IFX / 10 & 4.5 \\
\hline Smoking n (\%) & $1(20)$ & $1(16.7)$ & - & - & IFX / $14(43.8)$ & - \\
\hline Previous surgeries n (\%) & $5(100)$ & $\begin{array}{l}1(16.7) \text { - perianal } \\
\text { fistula }\end{array}$ & $59(39.4)$ & $67(45.5)$ & IFX / $8(25)$ & - \\
\hline 6-mercaptopurine & & & $22(14.7)$ & $19(13)$ & & \\
\hline Anti-TNF & & & $30(20)$ & $37(25.3)$ & IFX / $20(62.5)$ & - \\
\hline \multicolumn{7}{|c|}{ Concomitant immunosuppression, $\mathrm{n}(\%)$} \\
\hline None & & & - & - & IFX / $22(68.8)$ & \\
\hline Thiopurines & & & $27(18)$ & $21(14.3)$ & IFX / $8(25)$ & $40(70)$ \\
\hline Methotrexate & $5(100)$ & $6(100)$ & 0 & $4(2.7)$ & IFX / $2(6.3)$ & \\
\hline \multicolumn{7}{|l|}{ Disease location, $\mathrm{n}(\%)$} \\
\hline Ileal & & $2(33.4)$ & $146(97.3)$ & $144(98.6)$ & IFX / $16(50)$ & $7(21)$ \\
\hline Colonic & & $1(16.7)$ & $76(50.7)$ & $89(61)$ & IFX / 5 (15.6) & $6(18)$ \\
\hline Ileocolonic & $5(100)$ & $3(50)$ & & & IFX / $11(34.4)$ & $20(61)$ \\
\hline
\end{tabular}

CT: computed tomography; CD: Crohn's disease; UC: ulcerative colitis; IFX: infliximab; TNF: tumor necrosis factor; ADA: adalimumab.

\section{Results per included study}

Sorrentino et al. included patients underwent ileocolonic resection, who started IFX to prevent endoscopic recurrence, at a dose of $5 \mathrm{mg} / \mathrm{kg}^{(16)}$. After 3 years of surgery, colonoscopy was performed and no patient had recurrence, and IFX therapy was interrupted for all patients. After 4 months without treatment, $83 \%$ had endoscopic recurrence. Those with recurrence $(n=10)$ restarted IFX in a dose optimization study performed by the same team, which demonstrated that the dose of $3 \mathrm{mg} / \mathrm{kg}$ was sufficient to induce and maintain endoscopic remission for 1 year in all patients ${ }^{(20)}$. Five of these ten patients participated in the current study. Anti-IFX antibodies and serum levels (trough levels) of the drug were measured immediately before all infusions, which occurred every 8 weeks, and were compared to those of patients with $\mathrm{CD}$ who did not undergo surgery and who were in remission in one standard dose of $5 \mathrm{mg} / \mathrm{kg}$ of IFX. After additional 18 months, patients treated with $3 \mathrm{mg} / \mathrm{kg}$ of IFX underwent colonoscopy.

The mean values of serum levels of IFX were $4.75 \pm 0.83 \mu \mathrm{g} / \mathrm{mL}$ in controls (with usual doses of $5 \mathrm{mg} / \mathrm{kg}$ ), as compared to $2.0 \pm 0.3$ $\mu \mathrm{g} / \mathrm{mL}$ in patients treated with IFX $3 \mathrm{mg} / \mathrm{kg}(P<0.05)$. In four of the five patients treated with IFX $3 \mathrm{mg} / \mathrm{kg}$, the trough level of IFX was lower than $3 \mu \mathrm{g} / \mathrm{mL}$ while in all controls the trough level was greater than $3 \mu \mathrm{g} / \mathrm{mL}$. Antibodies were present in 2 of 5 patients treated with $3 \mathrm{mg} / \mathrm{kg}$ and in none of the controls. In the two patients with anti-IFX antibodies, their concentration was below $10 \mu \mathrm{g} / \mathrm{mL}$. All five patients evaluated in the treatment group had a Rutgeerts' score at 18 months of $\mathrm{i} 0$ or $\mathrm{i}$. TABLE 3 summarizes the drug and antibody concentrations and Rutgeerts' score of the five patients included in the study. The global MINORS score for the study was 22 , and its main bias was the heterogeneity of the sample, where the control group consisted of patients not submitted to ileocolonic resections, in addition to blinding bias.

TABLE 3. Infliximab (IFX) through levels, antibodies anti-IFX and Rutgeerts score of included patients ${ }^{(16)}$.

\begin{tabular}{lccccc}
\hline & Patient 1 & Patient 2 & Patient 3 & Patient 4 & Patient 5 \\
\hline $\begin{array}{l}\text { IFX through } \\
\text { level }(\mu \mathrm{g} / \mathrm{mL})\end{array}$ & $4.4 \pm 0.8$ & $0.91 \pm 0.1$ & $0.91 \pm 0.1$ & $1.3 \pm 0.3$ & $2.8 \pm 0.3$ \\
$\begin{array}{l}\text { Antibody } \\
\text { concentration } \\
(\mathrm{U} / \mathrm{mL})\end{array}$ & Negative & $5.4 \pm 0.3$ & Negative & $7.7 \pm 0.8$ & Negative \\
$\begin{array}{l}\text { Rutgeerts } \\
\text { score on } \\
\text { colonoscopy }\end{array}$ & i0 & i1 & i1 & i1 & i0 \\
\hline
\end{tabular}

The PREVENT multicenter study included 297 patients who underwent ileocolonic resection and were randomized in a 1:1 ratio into two groups: patients treated with intravenous infusion of IFX every 8 weeks or placebo ${ }^{(17)}$. Until week 76, endoscopic recurrence rates (Rutgeerts' score $\geq \mathrm{i} 2$ ) for the IFX and placebo groups were $22.4 \%$ and $51.3 \%$, respectively $(P<0.001)$. In patients treated with IFX, the serum level of the drug was measured at 
week 72 , and among patients who had endoscopic recurrence, $52.4 \%$ had levels lower than the lower limit of quantification $(0.1 \mu \mathrm{g} / \mathrm{mL}) ; 31.3 \%$ levels between 0.1 and $1.85 \mu \mathrm{g} / \mathrm{mL} ; 18.8 \%$ between $1,85 \mu \mathrm{g} / \mathrm{mL}$ and $4.44 \mu \mathrm{g} / \mathrm{mL} ; 26.7 \%$ between $4.44 \mu \mathrm{g} / \mathrm{mL}$ and $7.77 \mu \mathrm{g} / \mathrm{mL}$ and $13.3 \%$ had levels greater than $7.77 \mu \mathrm{g} / \mathrm{mL}$. Endoscopic recurrence until week 76 was observed in $64.7 \%$ (11 of 17 ), $46.7 \%$ (7 of 15 ) and $30.1 \%$ (22 out of 73 ) of patients positive, negative or with inconclusive levels for anti-IFX antibodies, respectively. The study showed a high risk of bias in relation to incomplete data on outcomes, but with a low risk of bias in all other determinants for assessing methodological quality.

Fay et al. demonstrated that among patients treated with IFX, lower trough levels (median, $1.1[0-0.6] \mu \mathrm{g} / \mathrm{mL}$ versus $2.4[0.45-4.1]$ $\mu \mathrm{g} / \mathrm{mL} P=0.008)$ and presence of anti-IFX antibodies $(1 / 18[5.6 \%]$ versus $10 / 14[71.4 \%], P=0.0001)$ were significantly related to the presence of PER ${ }^{(18)}$. Median levels of IFX were significantly higher in patients with a Rutgeerts' score of i0 as compared to those with a score of i4, as shown in TABLE 4 . When limited to anti-TNF naive patients $(n=20)$, the difference in IFX trough levels $(2.3$ $[0.3-3.8]$ versus $1.1[0.1-3.3] \mu \mathrm{g} / \mathrm{mL}, P=0.048)$ and antibodies (7.7\% versus $60 \%, P=0.044)$ remained significant. The MINORS score for this study was 7 , as it was a retrospective study and did not report on impartial analysis of the sample, follow-up period and loss of follow-up.

TABLE 4. Infliximab through levels stratified by Rutgeerts score of the included patients $(P=0.037)^{(18)}$

\begin{tabular}{lccccc}
\hline & $\begin{array}{c}\text { Rutgeerts } \\
\text { i0 }\end{array}$ & $\begin{array}{c}\text { Rutgeerts } \\
\text { i1 }\end{array}$ & $\begin{array}{c}\text { Rutgeerts } \\
\text { i2 }\end{array}$ & $\begin{array}{c}\text { Rutgeerts } \\
\text { i3 }\end{array}$ & $\begin{array}{c}\text { Rutgeerts } \\
\text { i4 }\end{array}$ \\
\hline $\begin{array}{l}\text { Through } \\
\text { level }\end{array}$ & 3.1 & 1.1 & 1.1 & 0.4 & 0.1 \\
$(\mu \mathrm{g} / \mathrm{mL})$ & $(0.1-4.1)$ & $(0.1-3.9)$ & $(0.5-3.6)$ & $(0.1-1.1)$ & $(0.1-3)$ \\
\hline
\end{tabular}

The pediatric study by Van Hoeve et al. obtained 686 serum level measurements during IFX maintenance therapy in 52 pediatric patients with inflammatory bowel disease (IBD) ${ }^{(19)}$. Endoscopic data were available at 87 times in 40 different patients after a median of 12.6 (12.6-22.4) months. In 54\% of visits to physicians' office, patients were in endoscopic remission at the time of the assessment $(n=47)$. The IFX trough levels used for comparison were measured at the time of colonoscopy if the patient received an IFX infusion on the same day. In all other cases, IFX trough levels were measured at the time of the nearest IFX infusion. The median serum IFX levels during maintenance were significantly higher in children who were in endoscopic remission (6.5 [4.2-9.5] $\mu \mathrm{g} / \mathrm{mL})$ as compared with those active disease at endoscopy (3.2 [2.3-5.6] $\mu \mathrm{g} / \mathrm{mL}, P=0.001)$. The same results were found when performing the diagnostic analysis (CD versus ulcerative colitis). The two postoperative patients who were included in the study did not have their data evaluated individually and did not provide conclusions about postoperative endoscopic recurrence related to serum IFX levels. The study presented a MINORS score of 9, as it is a retrospective cohort, with no data on impartial analysis, loss of follow-up and does not include consecutive patients.

\section{DISCUSSION}

Postoperative recurrence in CD has been studied since the early 90's. At that time, Rutgeerts et al. published their experience with patients who underwent ileocaecal resections and were followed for 8 years ${ }^{(4)}$. This study demonstrated the natural history of postoperative recurrence in $\mathrm{CD}$ and confirmed that endoscopic recurrence is the first to occur, in approximately $75 \%$ of patients after 1 year of surgery, preceding clinical symptoms, and showing the importance of controlling disease activity at an earlier stage.

Overall, rates of PER are vastly variable in the literature, suggesting approximately $10 \%$ in trials with biological therapy, and reaching up to $90 \%$ in patients without adequate postoperative management ${ }^{(5)}$. Anti-TNF therapy is increasingly used in the postoperative scenario in CD. However, data on the impact of serum levels and anti-drug antibodies in patients with CD after intestinal resection are lacking in relation to the risk of recurrence.

Two of the studies included in this review have a risk of bias related to the study population (reduced sample, absence of randomization, blinding and control group), heterogeneity between doses used, administration times, measurement of serum levels and even omission of the dose of the drug which was used, making the quality of the evidence not very robust ${ }^{(16,18)}$. Despite of that, the evidence found tends to confirm the correlation of endoscopic recurrence with low serum levels of IFX and the presence of antidrug antibodies.

The PREVENT study was the first large multicenter, randomized, placebo-controlled trial on the use of biologicals in patients with $\mathrm{CD}$ after ileocolonic resection ${ }^{(17)}$. The rate of endoscopic recurrence 18 months after surgery in patients treated with IFX was $22.4 \%$, remaining similar to most findings in the literature (which demonstrated endoscopic recurrence in 6 months of $21 \%$ in patients with anti-TNF therapy), against $51.3 \%$ in the placebo group. This study also demonstrated, with statistical significance, that lower serum IFX levels and the presence of antibodies against the drug are related to a higher risk of endoscopic recurrence. This study's data comprised the higher level of evidence published over the topic.

The pediatric study assessed exposure to IFX in children with IBD and its correlation with results of clinical, biological and endoscopic remission $^{(19)}$. This study represented the largest cohort of serum IFX levels in a pediatric population, and demonstrated, for the first time, a clear association between IFX trough levels and mucosal healing. However, such a study did not analyze the results separately between $\mathrm{CD}$ and ulcerative colitis, in addition to presenting only two patients in the postoperative period, who also did not have the data independently assessed. Thus, it was not possible to extract the data that meet the established inclusion criteria with accuracy. However, the study has a strong impact in the pediatric area, bringing for the first time the conclusion that children with IBD, treated with IFX under maintenance regimen, and in clinical and endoscopic remission, had significantly higher serum IFX levels, supporting the importance of proactive therapeutic monitoring to improve long-term results.

Several points still need to be better defined with regards to the correlation between serum levels of IFX and endoscopic recurrence. The best time for dosing after surgery has yet to be pointed. In addition, patients can be reinduced with the drug after surgical procedures. The best time point to perform colonoscopy for recurrence analysis, usually between 6-12 months, also needs to be better defined. However, despite these questions, there seems to be an association between absence of recurrence and higher mean serum levels of the drug. The interval between dosage and colonoscopy also varied in different studies, and in an ideal scenario, it should be kept to a minimum (endoscopic examination at the day of infusion, 
for example). However, current evidence in the literature seems to reflect in the postoperative scenario a significant relationship between higher levels and mucosal healing, in a similar way to luminal disease in patients who did not undergo surgery.

In the study by Fay et al., despite the significant difference between groups with or without PER, patients with no recurrence still had low serum levels of IFX $(2.4[0.45-4.1] \mu \mathrm{g} / \mathrm{mL})$, as the lower cutoff is usually $3.0 \mu \mathrm{g} / \mathrm{mL}$ in the maintenance phase ${ }^{(6,18)}$. A similar pattern was also identified in the study by Sorrentino et al., despite the reduced sample of analyzed patients ${ }^{(16)}$. One can speculate that even IFX levels lower than $3.0 \mu \mathrm{g} / \mathrm{mL}$ can be associated with absence of recurrence, mostly if antibodies to the drug are not detected. This topic deserves special attention in future studies, as the real lower cutoff in the postoperative scenario can be slightly different than in luminal disease, with no previous surgery.

The methodological limitations of this review should be noted. Databases such as Embase and Scopus were not screened due to technical difficulties. Therefore, the occurrence of publication bias cannot be ruled out, although the authors have tried to minimize it. Only four studies were included, with low or moderate methodological quality, presenting several problems such as blinding as well as restricted and often heterogeneous population sample, which makes the evaluation of results limited, and these should be interpreted with caution. The interval between dosage of
IFX serum levels and colonoscopy also varied in different studies, which represents an important limitation. In an ideal scenario, this interval should be kept to a minimum (endoscopic examination at the day of blood collection, for example).

Low serum levels of IFX and the presence of anti-IFX antibodies are associated with an increased probability of postoperative endoscopic recurrence in patients with CD who underwent ileocolonic resections. On the other hand, higher levels are associated to normal mucosal status and low Rutgeerts' score status (i0/i1). Strategies to optimize the dose of IFX, aiming at increased serum levels of the drug, should be better studied in the postoperative scenario to prevent or eliminate the problem of recurrence. Controlled and randomized clinical trials with adequate methodological quality are warranted to confirm the conclusions of this review.

\section{Authors' contribution}

Baraúna FSB and Kotze PG contributed to study conception and design; they also contributed to data collection and analysis, writing, editing, reviewing and gave final approval of the article.

\section{Orcid}

Fernanda da Silva Barbosa Baraúna: 0000-0002-5650-2937. Paulo Gustavo Kotze: 0000-0002-9632-6691.

Baraúna FSB, Kotze PG. Correlação entre níveis séricos de infliximabe e recorrência endoscópica pós-operatória em pacientes com doença de Crohn submetidos a ressecções ileocólicas: uma revisão sistemática. Arq Gastroenterol. 2021;58(1):107-13.

RESUMO - Contexto - As taxas de recorrência endoscópica pós-operatória em pacientes com doença de Crohn (DC) são significativas. A terapia anti-TNF é cada vez mais usada no cenário pós-operatório, apesar da escassez de dados na literatura sobre dosagem de níveis séricos e anticorpos da droga. Objetivo - Realizou-se uma revisão sistemática com o intuito de se avaliar níveis séricos de infliximabe (IFX) em pacientes com DC submetidos a ileocolectomia e correlacionar com a presença ou não de recorrência endoscópica da doença. Métodos - Buscou-se por estudos que avaliaram o nível sérico do IFX em pacientes com DC, submetidos a ileocolectomias, correlacionando-os à presença de recorrência endoscópica pós-operatória. Utilizou-se as bases de dados MEDLINE via PubMed e CENTRAL Cochrane Library, e após atingirem os critérios de inclusão, os estudos foram avaliados metodologicamente e foi realizada análise qualitativa dos dados. Resultados - Um total de 155 estudos foram identificados e apenas quatro atingiram os critérios de inclusão. Um era estudo de coorte prospectivo, o segundo era um ensaio clínico randomizado e dois eram estudos de coortes retrospectivas, sendo o último exclusivamente em pacientes pediátricos. As evidências encontradas tendem a confirmar a correlação da recorrência endoscópica a baixos níveis séricos de IFX e presença de anticorpos anti-droga. A qualidade da evidência gerada variou de muito baixa a alta, devido à heterogeneidade encontrada entre os estudos e o risco de viés identificado. Conclusão - Baixos níveis séricos do IFX e presença de anticorpos contra a droga estão associados a probabilidade aumentada de recorrência endoscópica pós-operatória nos pacientes com DC submetidos a ileocolectomias. Ensaios clínicos controlados e randomizados com adequada qualidade metodológica são necessários para confirmar as conclusões desta revisão.

DESCRITORES - Doença de Crohn. Recidiva. Infliximab. Monitoramento de medicamentos.

\section{REFERENCES}

1. de Barcelos IF, Kotze PG, Spinelli A, Suzuki Y, Teixeira FV, Albuquerque IC Factors affecting the incidence of early endoscopic recurrence after ileocolonic resection for Crohn's disease: a multicentre observational study. Colorectal Dis. 2017;19:O39-O45.

2. Armuzzi A, Felice C, Papa A, Marzo M, Pugliese D, Andrisani G, et al. Prevention of postoperative recurrence with azathioprine or infliximab in patients with Crohn's disease: An open-label pilot study. J Crohn's Colitis. 2013;7: e623-9.

3. Burr NE, Hall B, Hamlin PJ, Selinger CP, Ford AC, et al. Systematic review and network meta-analysis: Medical therapies to prevent recurrence of post-operative Crohn's disease. J Crohn's Colitis. 2018. Available from: https://academic.oup. com/ecco-jcc/advance-article/doi/10.1093/ecco jcc/jjy216/5250061.

4. Rutgeerts P, Geboes K, Vantrappen G, Beyls J, Kerremans R, Hiele M. Predictability of the postoperative course of Crohn's disease. Gastroenterology 1990;99: 956-63.
5. Kotze PG, Yamamoto T, Danese S, Teixeira V, Albuquerque IC, Saad-Hossne $\mathrm{R}$, et al. Direct Retrospective Comparison of Adalimumab and Infliximab in Preventing Early Postoperative Endoscopic Recurrence After Ileocaecal Resection for Crohn's Disease: Results from the MULTIPER Database. J Crohn's Colitis. 2015;541-7.

6. Mitrev N, Vande Casteele N, Seow CH, Andrews JM, Connor SJ, Moore GT, et al. Review article: consensus statements on therapeutic drug monitoring of anti-tumour necrosis factor therapy in inflammatory bowel diseases. Aliment Pharmacol Ther. 2017;46:1037-53.

7. Moore C, Corbett G, Moss AC. Systematic review and meta-analysis: Serum infliximab levels during maintenance therapy and outcomes in inflammatory bowel disease. J Crohn's Colitis. 2016;10:619-25.

8. Vande Casteele N, Ferrante M, Van Assche G, Ballet V, Compernolle G, Van Steen $\mathrm{K}$, et al. Trough concentrations of infliximab guide dosing for patients with inflammatory bowel disease. Gastroenterology. 2015;148:1320-9.e3. 
9. Maser EA, Villela R, Silverberg MS, Greenberg GR. Association of Trough Serum Infliximab to Clinical Outcome After Scheduled Maintenance Treatment for Crohn's Disease. Clin Gastroenterol Hepatol. 2006;4:1248-54.

10. Imaeda H, Bamba S, Takahashi K, Fujimoto T, Ban H, Tsujikawa T, et al. Relationship between serum infliximab trough levels and endoscopic activities in patients with Crohn's disease under scheduled maintenance treatment. J Gastroenterol. 2014;49:674-82.

11. Liberati A, Altman DG, Tetzlaff J, Mulrow C, Gøtzsche PC, Ioannidis JP, et al The PRISMA statement for reporting systematic reviews and meta-analyses of studies that evaluate health care interventions: explanation and elaboration. J Clin Epidemiol 2009;62:e1-34.

12. Moher D, Liberati A, Tetzlaff J, Altman DG; PRISMA Group. Preferred reporting items for systematic reviews and meta-analyses: the PRISMA statement. PLoS Med 2009;6:e1000097

13. Brasil. Ministério da Saúde. Secretaria de Ciência, Tecnologia e Insumos Estratégicos. Departamento de Ciência e Tecnologia. Diretrizes metodológicas: elaboração de revisão sistemática e metanálise de ensaios clínicos randomizados. Brasília : Editora do Ministério da Saúde, 2012. 92 p.: il. - (Série A: Normas eManuais Técnicos) ISBN 978-85-334-1951-3. Available from: http://bvsms.saude.gov.br/ bvs/publicacoes/diretrizes_metodologicas_elaboracao_sistematica.pdf.

14. Higgins JPT, Altman DG, Gøtzsche PC, Jüni P, Moher D, Oxman AD. The Cochrane Collaboration' $s$ tool for assessing risk of bias in randomised trials. BMJ 2011;343:d5928 doi: 10.1136/bmj.d5928
15. Slim K, Nini E, Forestier D, Kwiatkowski F, Panis Y, Chipponi J. Methodological Index for Non-Randomized Studies (MINORS) Development and Validation of a New Instrument. ANZ J Surg. 2003;73:712-716.

16. Sorrentino D, Marino M, Dassopoulos T, Zarifi D, Del Bianco T. Low Dose Infliximab for Prevention of Postoperative Recurrence of Crohn's Disease: Long Term Follow-Up and Impact of Infliximab Trough Levels and Antibodies to Infliximab. PLoS One. 2015;10:e0144900.

17. Regueiro M, Feagan BG, Zou B, Johanns J, Blank MA, Chevrier M, et al. Infliximab Reduces Endoscopic, but Not Clinical, Recurrence of Crohn's Disease After Ileocolonic Resection. Gastroenterology. 2016;150:1568-78.

18. Fay S, Ungar B, Paul S, Levartovsky A, Yavzori M, Fudim E, et al. The Association Between Drug Levels and Endoscopic Recurrence in Postoperative Patients with Crohn's Disease Treated with Tumor Necrosis Factor Inhibitors. Inflamm Bowel Dis. 2017;23:1924-9.

19. Van Hoeve K, Dreesen E, Hoffman I, Van Assche G, Ferrante M, Gils A, et al. Higher Infliximab Trough Levels Are Associated With Better Outcome in Paediatric Patients With Inflammatory Bowel Disease. J Crohns Colitis 2018;12(11):1316-25.

20. Sorrentino D, Paviotti A, Terrosu G, Avellini C, Geraci M, Zarifi D. Low-dose maintenance therapy with infliximab prevents postsurgical recurrence of Crohn's disease. Clin Gastroenterol Hepatol. 2010;8:591-9. 